\title{
The Impact of Internal Audit Quality on Financial Performance of Yemeni Commercial Banks: An Empirical Investigation
}

\author{
Saddam A. HAZAEA ${ }^{1}$, Mosab I. TABASH ${ }^{2}$, Saleh F.A. KHATIB ${ }^{3}$, Jinyu ZHU ${ }^{4}$, Ahmed A. AL-KUHALI
}

Received: August 01, 2020 Revised: September 30, 2020 Accepted: October 15, 2020

\begin{abstract}
Quality internal audit (IA) plays a crucial role in accountability, transparency and preserving public properties. This paper gives a brief background of the IA system in Yemen and examines its impact with regards to financial performance in Yemeni commercial banks based on five factors: (i) independence of IAs, (ii) adherence to IA standards, (iii) governance principles implementation, (iv) size of the IA, and (v) frequency of internal audits committees' meetings. The primary data for the study were collected through a questionnaire prepared for this purpose. Fifty questionnaires were distributed out of which forty-two were retrieved and valid in the analysis process. For the empirical analysis, descriptive analysis and T-test were used for verification of the research hypotheses. Results revealed that sticking to standards internal audit, internal auditors' independence and quality governance have significant impact on banks' financial performance, while the size of internal audits committees, as well as their meeting, frequently has insignificant positive impact on banks' performance. Moreover, the country results show that the use of automated internal audit in banks has an impact on improving financial performance. This article provides avenues for further studies, mainly in developing countries, including Yemen, in quality internal audit and financial performance.
\end{abstract}

Keywords: Internal Audit Effectiveness, Commercial Banks, Financial Performance, Yemen

JEL Classification Code: G21, M4

\section{Introduction}

In the last two decades, a series of financial scandals and collapses have happened in several international corporations. For instance, the collapses of the World Telecom firm of America in 2002 and Enron in the United States in 2001 that works in the field of marketing electricity and natural gas, which was called a sense of honesty and

${ }^{1}$ First Author. [1] School of Accounting, Yunnan University of Finance and Economics, Kunming, China [2] College of Administration and Human Science, Al-Jazeera University, Ibb, Yemen.

${ }^{2}$ Corresponding Author. College of Business, Al Ain University, Al Ain, UAE [Postal Address: 30 Street, Al Ain, Abu Dhabi, 64141, UAE] Email: mosab.tabash@aau.ac.ae

${ }^{3}$ Department of Management, Azman Hashim International Business School, Universiti Teknologi Malaysia, Johor Bahru, Malaysia

${ }^{4}$ School of Accounting, Yunnan University of Finance and Economics, Kunming, China.

${ }^{5}$ School of Management, Lanzhou University, Lanzhou, China.

(C) Copyright: The Author(s)

This is an Open Access article distributed under the terms of the Creative Commons Attribution Non-Commercial License (https://creativecommons.org/licenses/by-nc/4.0/) which permits unrestricted non-commercial use, distribution, and reproduction in any medium, provided the original work is properly cited. transparency, led to a loss of confidence in such companies and their demise pointed to the disappearance of the tight internal audit IA concept and the absence of a governance system. In light of the high pressure of competition at the local and international levels, internal auditing, and its relationship to corporate governance, has become important issues. For international institutions and companies to ensure their survival, continuity, and competition with companies active in the same industry, and to determine the impact of IA as a governance mechanism, the Institute of Internal Auditors developed international standards for internal auditing, and the (OECD) Organization for Economic Cooperation and Development worked to create the principles of monitoring mechanisms to meet fierce international competition. This is what made both audit and corporate governance a tool for adding value to the institutions by their monitoring and consulting services, in addition to disclosure.

In today's business world, many firms have adopted various governing and monitoring tools because of the increase of the competitiveness and economic demands including internal auditing systems. According to IIA (2011), the IA is an objective and independent activity to increase the quality of the operation of institutions and work to add 
value to them. As suggested by the Chartered Institute of Internal Auditors (2017), the main reason for the emergence of the need for audits (internal, external) is the separation of ownership of institutions from their departments, so that the audit includes the examination and control process to report their view on the quality and reliability of the financial statements. IA functions and the quality of the institutions' financial reports have a significant positive association, which contributes to achieving competition (Alzoubi, 2019).

Auditing quality plays an important role in protecting companies from the risks of the crash, which is the goal that all institutions pursue, meaning that institutions whose operations are audited by professional auditors face less risk (Chae et al., 2020). IA is one of the most important aspects contributing to adding value to institutions by improving the monitoring and follow-up process to improve outputs (Coram et al., 2008). Also, IA is a significant tool to maximize businesses outcomes for institutions (Drogalas et al., 2015). The efficiency of IA exerts a high positive impact on adding value to the work and improving performance (Postula et al., 2020). There is a positive complementary correlation between the independence of the IA, accounting experience of the auditors, regular meetings of the internal audit, and the effectiveness of the IA (Goodwin-Stewait \& Kent, 2006). Many factors contribute to enhancing the effectiveness of IA, including their contribution to improving the institutions' outputs, the most important of which are independence, following international standards, continuous training of auditors, and the use of modern control systems (Hazaea et al., 2020).

Financial performance in banks is affected by many factors, including what is related to auditing, and some of these factors are related to management. According to Majeed et al. (2020), the size of the bank's board of directors positively correlates with the return on assets, while it is negatively related to the return on shareholders' equity, which are two basic measures for determining financial performance. Financial performance requires enhancing appropriate efficiency to IA practices (Ondieki, 2013). The primary objective of this paper is to examine the extent of the impact of the IA system on raising financial performance in commercial banks. Therefore, this research investigates the link between the quality of IA system and financial performance in Yemen. The rest of this paper is structured as follows. In part 2, we present a review of the relevant studies. Part 3 discusses the methodology employed in this paper and the results of the paper are interpreted. Part 4 concludes the paper. Limitations and future studies are given in part 5.

\section{Literature Review}

The internal audit (IA) contributes to activating the public sector institutions in a way that contributes to achieving its goals (Enofe et al., 2013). According to research by Alzeban and Gwilliam (2014), there are many issues that contribute to activating the role of IA in corporations such as the independence and efficiency of the IA system. Many aspects contribute to enhancing the efficiency of internal auditing, some of which are linked to auditors, such as independence and objectivity, and some are related to senior management, such as providing the necessary support for auditing management so that the work can be carried effectively (Dellai \& Omri, 2016). The independence of members of audit committees is positively related to the quality of profits in institutions and companies, and therefore heads of boards of departments should not be involved as members of audit committees because of its negative impact on performance and quality of profits (Al-Absy et al., 2020). If the internal auditors followed the standards that regulate the profession of IA which will leads to contribute positively to improving and regularizing performance (Getie Mihret et al., 2010).

Indeed, strengthening the audit department independence, regular meetings, and continuous training of auditors to keep pace with the modernization of international standards that regulate the profession of audit activities, contribute significantly to enhancing the performance of institutions (Hazaea et al., 2020). If the internal auditors follow the rules and procedures that regulate the profession of internal auditing, including following the standards is one of the most vital factors that help in refining performance (Arena et al., 2006). Corporate governance is strongly correlated with IA. Internal audit assists boards of directors of institutions in discharging its governance responsibilities, leading to improved performance and the achievement of competition (Florea \& Florea, 2013). Well-governance structure is closely linked to improving corporate performance (Bhagat $\&$ Bolton, 2008).

The results of the study by Al-ahdal et al. (2020) reported that monitoring mechanisms have an impact on financial performance in companies, which enhances their role in achieving their goals. Furthermore, their findings showed that audit committees have a small part in improving companies' financial performance. The firm performance is associated with the monitoring activities within the organizations. Still, this relationship is not reliable, and therefore, the impact of corporate governance on performance is minimal and is related to synchronization, heterogeneity, and dynamic organizational outcomes (Akbar et al., 2016). Correctly practicing corporate governance within institutions contributes to enhancing performance, adding value, and improving these companies' economic and statistical performance (Ammann et al., 2011). Corporate governance increases the prices of shares of fixed companies, which contributes to an increase and grow in the company's total value (Ararat et al., 2017). 
The independence of the members in charge of auditing in institutions, the frequency of their meetings periodically, and regularly, in addition to the $\mathrm{AC}$ size, have a positive impact on the performance of institutions and improving their outputs (Bansal \& Sharma, 2016). If the size of audit committees is large, this will lead to a lack of interest in the work more and lack of cooperation among the auditors (Drakos \& Bekiris, 2010). Ujunwa et al. (2012) argued that having appropriate members (audit committee size) in the internal audit department benefits both appropriately and substantially in obtaining different types of knowledge, opinions, and proposals that are useful in various institutional investments in a way that benefits institutions.

According to the study by Rahman et al. (2019), which discussed the extent of the impact of the audit characteristics on the financial performance of companies, the size of the audit committees is positively correlated with the financial performance because the large size of the audit committees may undoubtedly include some members who possess various professional experiences (accounting, and finance), which may contribute to solving problems and facing the difficulties and challenges faced by companies, and consequently improving firm performance. If the size of the auditors (audit committees) is large, this will lead to a lack of interest in the work more and a lack of cooperation among the auditors to make sound decisions. Hence, their knowledge and skill remain unutilized (Dharmadasa et al., 2015). Authority systems play a major role in the positive and negative IA. Democratic systems support the independence of IA, which contributes to improving performance, on the contrary, in a monarchy system (Hazaea et al., 2020). Table 1 provides a sample of the empirical studies from different contexts.

Through previous studies, we summarized the factors that affect financial performance when using the internal audit system in order to study and discuss the topic clearly and smoothly. In Table 2 we expressed the association between IA and financial performance using $(+-)$ and mixed signals according to what we have come up with Results from previous studies.

Table 1: Some example of empirical articles on commercial banks

\begin{tabular}{|l|l|c|c|c|}
\hline Authors & \multicolumn{1}{|c|}{ Sample and country } & Time limit & Data collection & Analysis techniques used \\
\hline Ondieki (2013) & $\begin{array}{l}20 \text { commercial banks } \\
\text { Kenya }\end{array}$ & 2012 & Questionnaire & $\begin{array}{c}\text { Multiple regression Descriptive } \\
\text { statistics. Average percentage } \\
\text { Standard deviation Covariance }\end{array}$ \\
\hline $\begin{array}{l}\text { Hazaea,Zhu, } \\
\text { Alsharabi, et al. } \\
(2020) .\end{array}$ & $\begin{array}{l}7 \text { commercial banks } \\
\text { Yemen }\end{array}$ & 2019 & Questionnaire & $\begin{array}{c}\text { Average percentage Standard } \\
\text { deviation Covariance }\end{array}$ \\
\hline Dianita (2015) & Indonesia & $2012-2014$ & Secondary data & Questionnaire \\
\hline Kasiva (2012) & $\begin{array}{l}44 \text { commercial banks/ } \\
\text { Kenya }\end{array}$ & 2012. & $\begin{array}{l}\text { Multiple regression Descriptive } \\
\text { analysis }\end{array}$ \\
\hline Awdat (2015) & $\begin{array}{l}13 \text { commercial bank } \\
\text { Jordan }\end{array}$ & 2015 & Questionnaire & $\begin{array}{l}\text { Multiple regression Descriptive } \\
\text { analysis }\end{array}$ \\
\hline $\begin{array}{l}\text { Robin et al. } \\
(2018)\end{array}$ & $\begin{array}{l}13 \text { commercial banks } \\
\text { Bangladesh }\end{array}$ & $1983-2012$. & secondary data & $\begin{array}{l}\text { Multiple regression Descriptive } \\
\text { analysis and Correlation matrix }\end{array}$ \\
\hline $\begin{array}{l}\text { Deribe \& } \\
\text { Regasa (2014) }\end{array}$ & $\begin{array}{l}15 \text { commercial banks } \\
\text { Ethiopian }\end{array}$ & 2014 & Questionnaire & $\begin{array}{l}\text { Multiple regression Descriptive } \\
\text { analysis }\end{array}$ \\
\hline
\end{tabular}

Table 2: Main factors affecting financial performance

\begin{tabular}{|l|c|l|c|}
\hline Item & Relationship & \multicolumn{1}{|c|}{ Item } & Relationship \\
\hline Quality of IA & ${ }^{*}+$ & Competence of IA team & + \\
\hline Independence of IA & ${ }^{*}+$ & Governance & + \\
\hline Size of IA & + +/ & Frequency of meetings & + \\
\hline Followed the international standards & + & Management support & +- \\
\hline Modern control system & ${ }^{*}+$ & Authority systems & $+/-$ \\
\hline
\end{tabular}

$\left({ }^{*}+\right)$ indicate that these items have a very high and positive impact $(+)$ indicate that these items have a high and positive impact $(+/-)$ indicate that these items have an impact (positive or negative) depends on the process. 


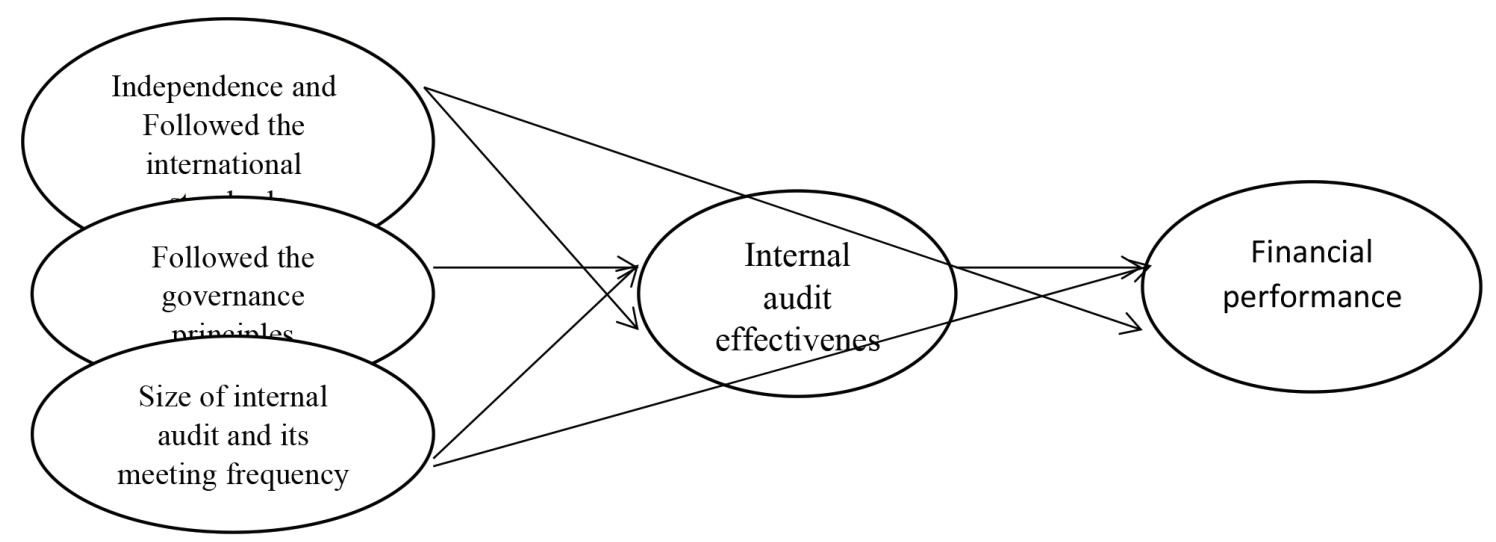

Figure 1: The research framework

\subsection{Conceptual Framework}

The framework of the research illustrates the association between the dependent variable and explanatory variables of this study. It depicts that four factors may influence internal audit adoption among commercial banks. The independent variables are independence, international standards, and governance principles, size of IA, and frequency meetings of internal audits while the dependent variable is financial performance adoption. Three hypotheses were developed to measure the effect of IA on financial performance in Yemeni commercial banks.

H1: Independence of internal auditors and following the IA standards have a positive effect on improving financial performance.

H2: Governance principles implemented in commercial banks have a positive effect on improving financial performance.

H3: Size of IA and frequency meetings of internal auditors affect to enhance financial performance in commercial banks.

\subsection{Auditing and Commercial Banks in Yemen}

Yemen started the process of comprehensive economic reform in 1994 after achieving unity between the North and South in 1990 and aims to achieve stability and economic growth. The process of economic reform was launched in parallel with the completion of the structure of the banking sector by establishing the Central Bank of Yemen and 11 commercial banks owned by the government sector, private and mixed in addition to the presence of two banks owned by foreign investors. The banking sector faced from 1990 to 1994 many difficulties and challenges for several reasons, including the lack of modern auditing systems, the absence of control systems, the lack of competent auditors that enables them to contribute to raising the level of auditing, besides the political and economic problems at that time (Qatinah, 2012). On the other hand, the auditing profession started in Yemen after the Yemeni Unification was achieved in 1990 with the establishment of the Central Organization for Control and Auditing in 1992, which contributed significantly to the establishment of audits and oversight to preserve public and private property (Al-Iryani, 1992). With the beginning of the year 2000, the actual development of the audit in Yemen started by issuing government laws as well as interest from the private sector. With all this interest and development, however, the audit in Yemen face many difficulties, the most important of which is the lack of a sufficient number of auditors with professional experience (accounting and financial), lack of clarity and the true importance of the audit system, especially for private-sector owners, failure to keep pace the use of modern systems, in addition to not fully following international standards for auditing (Hazaea et al., 2020).

\section{Methodology}

\subsection{Population and Sample Size}

This research was conducted on the Yemeni commercial banks by the end of 2019. The study population includes 10 Yemeni commercial banks. The sample comprises of auditors working in Yemeni commercial banks 50, $(\mathrm{N}=42)$. The researchers utilized a survey to collect the data. The respondents of the research were auditors working in Yemeni commercial banks, limited to internal audit departments as these respondents are a good subject to achieve the research objectives. In this study, the statistical package of social sciences (SPSS) was utilized to analyze the collected data. The observations were encoded based on the 5-point Likert 
scales for measuring trends as it is reasonably simple to be understood from respondents. Also, it has been highlighted that such a scale is more reliable (Lam \& Kolic, 2008). The value 1 was given where the paragraph is completely unavailable (strongly disagreed). The value 2 (disagreed), 3 (undesired), 4 (agreed), and 5 were given to rank the answer. For instance, in case that the paragraph is fully available, the number 5 was given. The hypothetical mean used for the study is 3 and it is given by the following formula:

$$
\mu=(1+2+3+4+5)=15 / 5=3
$$

This implies that if the estimated mean is higher than the conceptual average of study 3, then this paragraph is undoubtedly available. In case that the estimated mean of the observations is less than the hypothetical means of the study, it shows that the paragraph is not available. Whereas, if the estimated mean is close to 3 shows indecision or offsetting differences.

\subsection{Data Analysis and Results}

\subsubsection{Descriptive Analysis}

Table 3 shows that the general mean average of the first hypothesis is 3.49 , which is higher than the hypothetical average of this study (3). This shows that the independence of internal audits and following the IA standards positively affect the financial performance in commercial banks. These results are consistent with findings suggested by Alzeban and Gwilliam (2014) and Getie Mihret et al. (2010) who reported a positive impact existence between the independence of auditors and financial outcomes and a similar result for the association between the financial performance and following international standards.

Quality of the audit represented in the auditors' enjoyment of adequate financial and accounting experience, independence has a positive and important influence on financial performance (Phan et al., 2020). The mean of the second and third hypotheses (3.81-3.41), respectively, which is higher than the average mean of the hypothesis (3), indicates that governance has a positive and high impact on the financial performance in commercial banks, and the meetings frequency of the audit committees and its size affect the financial performance. This is in line with Ugwu et al. (2020), which confirmed that the size of the audit committees improves the financial performance in Nigerian commercial banks. Also, Ado et al. (2020) find that the audit committees' size, the independence of auditors, positively improves financial performance in Nigerian companies. Owusu (2012) suggested that corporate governance primarily supports improving corporate performance, which helps in achieving profitability. This is also achieved and reported by Al-ahdal et al. (2020).

\subsubsection{T-test Analysis}

To test the hypotheses, the researchers used the mean and standard deviations and, then, the general mean as well as the standard deviation were calculated in order to know the degree of agreement among the sample members on the hypotheses. In order to know the significance of the differences between the averages of the hypotheses and the average of the five-point scale used in this study, which is 3 , T-test was used (single sample test). A T-test is used to find the differences between the average of the results obtained and the central mean of the study (Ruxton, 2006). This is also confirmed by $\mathrm{Kim}$ (2015). This is to judge the degree of approval where the hypothesis is a statistical function if the calculated value of $\mathrm{T}$ is greater than 3 at the level of significance approved in this study (0.05). It means agreeing to this hypothesis, while if the value of the significance level is greater than (0.05) this indicates that the answers of the sample members are dispersed and not clear.

Table 3: Descriptive statistics

\begin{tabular}{|l|c|c|c|c|c|c|c|}
\hline Variable & $\mathbf{N}$ & Mean & Standard division & Minimum & Maximum & T-test & Sig \\
\hline ISIA & 42 & 3.49 & 1.02 & 1.11 & 5.00 & 3.15 & .00 \\
\hline GPIA & 42 & 3.81 & 1.07 & 1.08 & 5.00 & 4.89 & .00 \\
\hline SMIA & 42 & 3.41 & 1.15 & 1.00 & 5.00 & 2.31 & .03 \\
\hline Average mean & 3.57 & 1.08 & & & 3.45 & \\
\hline
\end{tabular}

Table 4: One sample T-test $(\mathrm{H} 1)$

\begin{tabular}{|l|c|c|c|c|c|}
\hline \multicolumn{5}{|l|}{ Test Value $=3$} \\
\hline Confidence interval of the Difference 95\% \\
\hline $\mathbf{T}$ & DF & Sig. (tailed-2) & Mean Difference & Lower & Upper \\
\hline M9 -3.15 & 41 & .003 & .49471 & .1779 & .8115 \\
\hline
\end{tabular}


Table 5: One sample T-test $(\mathrm{H} 2)$

\begin{tabular}{|l|l|c|c|c|c|}
\hline \multicolumn{5}{|l|}{ Test Value $=3$} \\
\hline Confidence interval of the Difference 95\% \\
\hline $\mathbf{T}$ & DF & Sig. (tailed-2) & Mean Difference & Lower & Upper \\
\hline M12- 4.89 & 41 & .000 & .80754 & .4738 & 1.1413 \\
\hline
\end{tabular}

Table 6: One sample T-test(H3)

\begin{tabular}{|c|c|c|c|c|c|}
\hline Test Value & & & & & \\
\hline Confidence & biffere & & & & \\
\hline$T$ & DF & Sig. (tailed-2) & Mean Difference & Lower & Upper \\
\hline M11- 2.31 & 41 & .026 & .40909 & .0511 & .7671 \\
\hline
\end{tabular}

Table 7: Main factors affecting financial performance in Yemeni commercial banks

\begin{tabular}{|l|c|l|c|}
\hline Item & relationship & Item & relationship \\
\hline Quality of IA & + & Competence of IA team & + \\
\hline Independence of IA & ${ }^{*}$ & Governance & + \\
\hline Size of IA & $=$ & Frequency of meetings & $=$ \\
\hline Followed the international standards & + & Management support & $\wedge$ \\
\hline Modern control system & $+^{*}$ & Authority systems & $\wedge$ \\
\hline
\end{tabular}

$\left({ }^{*}+\right)$ indicate that these items have a very high and positive impact $(+)$ indicate that these items have a high and positive impact $(=)$ indicate that these items have a normal impact $\left(^{\wedge}\right)$ indicate that these items have not been investigating in this study

H1: T-test results for one sample indicated that there are no statistically significant differences between the first hypothesis and the value approved in this study (3), where the value of $\mathrm{T}$ calculated is 3.15 , which is more than the value $\mathrm{T}$ approved in the study threshold (3). The moral significance is smaller than the level of the significance approved in this study (0.05), which confirms the degree of approval of the opinions of the sample on this hypothesis. This means that the independence of internal auditors and following the IA standards have a positive effect to improve financial performance in commercial banks. This is in line with Ondieki (2013), which reported that the independence of the members of the audit committees, the professional standards for IA, the competence of professional auditors, whether financial or accounting, as well as internal control, have a significant positive relationship in improving and enhancing financial performance in commercial banks. Fin (2020) argued that improved performance in institutions is greatly influenced by the independence of the internal audit.

H2: T-test results for one sample showed that there are no statistically significant differences between the second hypothesis and the value approved in this study (3), where the value of $\mathrm{T}$ calculated is 4.89 , which is more than the value $\mathrm{T}$ approved in the study threshold (3). The moral significance is smaller than the level of the significance approved in this study (0.05), which confirms the degree of approval of the opinions of the sample on this hypothesis. This indicates that governance has a positive and high impact on financial performance. This result in line with the conclusion of Dianita (2015) which showed that governance has a significant and positive influence on financial performance.

H3: T-test results for one sample presented that there are statistically significant differences between the second hypothesis and the value approved in this study (3), where the value of $\mathrm{T}$ calculated is 2.31 , which is lowest than the value $\mathrm{T}$ approved in the study threshold (3). The moral significance is smaller than the level of the significance approved in this study (0.05). This indicates the dispersion of the opinions of the sample members on this hypothesis. There is an association between the size of the audit (audit committees, the frequency of meetings, and financial performance), but it is not important. This indicates that the size of the audit (audit committees, the frequency of meetings), has a positive insignificant impact on the financial performance. As the effect is normal and does not contribute significantly to improving financial performance (Aanu et al., 2014). According to Rahman et al. (2019) the 
audit committee meetings do not have a positive impact on the financial performance of the companies.

Through the previous analysis, we can summarize what has been reached about the factors that affect financial performance in Yemeni commercial banks in the following table.

\section{Conclusion and Recommendations}

This paper aims to clarify the impact of the (IA) system on the financial performance of the Yemeni banking sector. This research relied on preliminary data collected via the survey (Questionnaires) distributed to 10 Yemeni commercial banks operating under the supervision of the Central Yemeni Bank. Emphasis was placed on some of the factors that contribute to increasing the effectiveness of IA, such as the independence of auditors, governance, following relevant international standards, size of $\mathrm{AC}$, and the frequency of meetings. Descriptive analysis was also used as well as the $\mathrm{T}$ independent test, which showed a significant impact of the IA system on commercial banks' financial performance. The result shown in Table 7 indicates that the independence of the auditors, following the relevant international auditing standards that govern the workflow in addition to governance, have a significant and positive impact in improving financial performance in commercial banks, while the results show that the size of the IA department (AC) has a positive effect, but insignificant, in addition to that there is little positive impact concerning the frequency of meetings of audit committees and auditors on improving the financial performance of commercial banks.

This research recommends that the members of the IA should have professional and accounting experience, that the number of auditors is commensurate with the size of the work, they should be given full independence when performing their work, in addition to the need to ensure that the auditors' meetings are specifically designed for issues that enhance and assist in improving financial performance. This paper is useful for academics, policymakers, and practitioners. Also, the current study contributes to the limited segments of literature on IA system in Yemen.

\section{Limitation and Future Studies}

The interpretation of our results should be made considering the following. The findings of this paper are limited to verifying the influence of some factors on financial performance and limiting this research to 10 commercial banks only. Future studies are recommended to expand the scope to include all commercial banks that operate under the administration and control of the Central Bank of Yemen in addition to the expansion in the search for the impact of other aspects on financial performance, such as the authority system, as well as the relationship of the external auditor.

\section{References}

Aanu, O., Odianonsen, I., \& Foyeke, O. (2014). Effectiveness of Audit Committee and Firm Financial Performance in Nigeria: An Empirical Analysis. Journal of Accounting and Auditing: Research \& Practice, 1-12. https://doi. org/10.5171/2014.301176

Ado, A. B., Rashid, N., Mustapha, U. A., \& Ademola, L. S. (2020). The impact of audit quality on the financial performance of listed companies nigeria. Journal of Critical Reviews, 7(9), 3742. https://doi.org/10.31838/jcr.07.09.07

Akbar, S., Poletti-Hughes, J., El-Faitouri, R., \& Shah, S. Z. A. (2016). More on the relationship between corporate governance and firm performance in the UK: Evidence from the application of generalized method of moments estimation. Research in International Business and Finance, 38, 417-429. https://doi. org/10.1016/j.ribaf.2016.03.009

Al-Absy, M. S. M., Ismail, K. N. I. K., Chandren, S., Al-Dubai, S. A. A., Nor, K., Ku, I., \& Chandren, S. (2020). Involvement of Board Chairmen in Audit Committees and Earnings Management: Evidence from Malaysia. Journal of Asian Finance, Economics and Business, 7(8), 233-246. https://doi. org/10.13106/jafeb.2020.vol7.no8.233

Al-ahdal, W. M., Alsamhi, M. H., Tabash, M. I., \& Farhan, N. H. S. (2020). The impact of corporate governance on financial performance of Indian and GCC listed firms: An empirical investigation. Research in International Business and Finance, 51,101083. https://doi.org/10.1016/j.ribaf.2019.101083

Al-Iryani, A. M. (1992). Audit profile: republic of Yemen-the central organization. International Journal of Government Auditing, 19(1), 1-15.

Alzeban, A., \& Gwilliam, D. (2014). Factors affecting the internal audit effectiveness: A survey of the Saudi public sector. Journal of International Accounting, Auditing and Taxation, 23(2), 74-86. https://doi.org/10.1016/j.intaccaudtax.2014.06.001

Alzoubi, E. S. S. (2019). Audit committee, internal audit function and earnings management: evidence from Jordan. Meditari Accountancy Research, 27(1), 72-90. https://doi.org/10.1108/ MEDAR-06-2017-0160

Ammann, M., Oesch, D., \& Schmid, M. M. (2011). Corporate governance and firm value: International evidence. Journal of Empirical Finance, 18(1), 36-55. https://doi.org/10.1016/j. jempfin.2010.10.003

Ararat, M., Black, B. S., \& Yurtoglu, B. B. (2017). The effect of corporate governance on firm value and profitability: Timeseries evidence from Turkey. Emerging Markets Review, 30, 113-132. https://doi.org/10.1016/j.ememar.2016.10.001

Arena, M., Arnaboldi, M., \& Azzone, G. (2006). Internal audit in Italian organizations. A multiple case study. Managerial Auditing Journal, 21(3), 275-292. https://doi. org/10.1108/02686900610653017 
Awdat, A. A. (2015). (2015). The impact of the internal audit function to improve the financial performance of commercial banks in Jordan utautcaat. Research Journal of Finance and Accounting, 6(3), 217-226.

Bansal, N., \& Sharma, A. K. (2016). Audit Committee, Corporate Governance and Firm Performance: Empirical Evidence from India. International Journal of Economics and Finance, 8(3), 103. https://doi.org/10.5539/ijef.v8n3p103

Bhagat, S., \& Bolton, B. (2008). Corporate governance and firm performance. Journal of Corporate Finance, 14(3), 257-273. https://doi.org/10.1016/j.jcorpfin.2008.03.006

Chae, S. J., Nakano, M., \& Fujitani, R. (2020). Financial reporting opacity, audit quality and crash risk: Evidence from Japan. Journal of Asian Finance, Economics and Business, 7(1), 9-17. https://doi.org/10.13106/jafeb.2020.vol7.no1.9

Chartered Institute of Internal Auditors (2017). What is internal audit? Retrieved 18 December 2017 from https://na.theiia.org/ about-us/about-ia/Pages/frequently-asked-questions.aspx

Coram, P., Ferguson, C., \& Moroney, R. (2008). Internal audit, alternative internal audit structures and the level of misappropriation of assets fraud. Accounting and Finance, 48(4), 543-559. https://doi.org/10.1111/j.1467629X.2007.00247.x

Dellai, H., \& Omri, M. A. B. (2016). Factors Affecting the Internal Audit Effectiveness in Tunisian Organizations. Research Journal of Finance and Accounting, 7(16), 208-221.

Deribe, W. J., \& Regasa, D. G. (2014). Factors Determining Internal Audit Quality: Empirical Evidence from Ethiopian Commercial Banks. Research Journal of Finance and Accounting, 5(23), 86-95.

Dharmadasa, P., Gamage, P., \& Herath, S. K. (2015). Corporate Governance and Firm Performance: Evidence from Sri Lanka. South Asian Journal of Management, 21(1), 7-31. https://doi. org/10.15640/jfbm.v3n1a16

Dianita, M. (2015). Role of the Internal Auditor Influence and Good Corporate Governance in Banking Financial Performance Against State Owned Corporation. International Journal of Business and Administrative Studies, 1(4), 176-179. https://doi. org/10.20469/ijbas.10006-4

Drakos, A. A., \& Bekiris, F. V. (2010). Endogeneity and the relationship between board structure and firm performance: a simultaneous equation analysis for the Athens Stock Exchange. Managerial and Decision Economics, 31(6), 387-401. https:// doi.org/10.1002/mde.1492

Drogalas, G., Karagiorgos, T., \& Arampatzis, K. (2015). Factors associated with Internal Audit Effectiveness: Evidence from Greece. Journal of Accounting and Taxation, 7(7), 113-122. https://doi.org/10.5897/jat2015.0182

Enofe, D. A. O., Mgbame, D. C. J., Osa-Erhabor, V. E., \& Ehiorobo, A. J. (2013). The Role of Internal Audit in Effective Management in Public. Research Journal of Finance and Accounting, 4(6), 162-168.

Fin, A. J. M. A. (2020). Effect of audit quality on financial performance of listed manufacturing firms in Nigeria (2006-
2016). Advance Journal of Management, Accounting and Finance, 5(1), 1-12.

Florea, R., \& Florea, R. (2013). Internal Audit and Corporate Governance. Economy Transdisciplinarity Cognition, 16(1), 79-83.

Getie Mihret, D., James, K., \& Mula, J. M. (2010). Antecedents and organisational performance implications of internal audit effectiveness: Some propositions and research agenda. Pacific Accounting Review, 22(3), 224-252. https://doi. org/10.1108/01140581011091684

Goodwin-Stewait, J., \& Kent, P. (2006). Relation between external audit fees, audit committee characteristics and internal audit. Accounting and Finance, 46(3), 387-404. https://doi. org/10.1111/j.1467-629X.2006.00174.X

Hazaea, S. A., Zhu, J., Alsharabi, N., Khatib, S. F. A., \& Yueying, L. (2020). On The Effectiveness of Audit Committee Characteristics in Commercial Banks: Evidence from Yemen. Journal of Critical Reviews, 7(18), 2096-2115.

Hazaea, S. A., Zhu, J., Khatib, S. F. A., \& Arshad, M. (2020). A Comparative Study of The Internal Audit System Between China and The Gulf Cooperation Council Countries. Proceeding on Business, Economy, Management and Social Studies towards Sustainable Economy, 1(1), 1-7. https://doi. org/10.31098/bemss.v1i1.5

IIA (2011). Measuring internal audit effectiveness and efficiency. $I P P F-$ Practice guide. The Institute of Internal Auditors.

Kasiva, M. V. (2012). The impact of risk based audit on financial performance in commercial banks in Kenya. University of Nairobi.

Kim, T. K. (2015). T test as a parametric statistic. Korean Journal of Anesthesiology, 68(6), 540. https://doi.org/10.4097/ kjae.2015.68.6.540

Lam, T.C.M., \& Kolic, M.(2008). Effects of semanticincompatibility on rating response. Applied Psychological Measurement, 32(3), 248-260. https://doi.org/10.1177/0146621607301094

Majeed, M. K., Jun, J. C., Zia-Ur-Rehman, M., Mohsin, M., \& Rafiq, M. Z. (2020). The board size and board composition impact on financial performance: An evidence from the Pakistani and Chinese's listed banking sector. Journal of Asian Finance, Economics and Business, 7(4), 81-95. https://doi. org/10.13106/jafeb.2020.vol7.no4.81

Ondieki, N. M. (2013). Effect of internal audit on financial performance of commercial banks in Kenya. University of Nairobi. http://hdl.handle.net/20.500.12306/5437

Owusu, A. (2012). An empirical investigation of the relationship between corporate governance and firm performance: evidence from Ghana. Robert Gordon University. Available from: http:// openair.rgu.ac.uk

Phan, T. T. H., Lai, L. A., Le, T. T., Tran, D. M., \& Tran, D. T. (2020). The impact of audit quality on performance of enterprises listed on Hanoi Stock Exchange. Management Science Letters, 10(1), 217-224. https://doi.org/10.5267/j.msl.2019.8.001 
Postula, M., Irodenko, O., \& Dubel, P. (2020). Internal Audit as a Tool to Improve the Efficiency of Public Service. European Research Studies Journal, XXIII(3), 699-715. https://doi. org/10.35808/ersj/1663

Qatinah, A. (2012). Banking Sector in Yemen. Philipps Universität Marburg.

Rahman, M. M., Meah, M. R., \& Chaudhory, N. U. (2019). The impact of audit characteristics on firm performance: An empirical study from an emerging economy. Journal of Asian Finance, Economics and Business, 6(1), 59-69. https://doi. org/10.13106/jafeb.2019.vol6.no1.59

Robin, I., Salim, R., \& Bloch, H. (2018). Financial performance of commercial banks in the post-reform era: Further evidence from Bangladesh. Economic Analysis and Policy, 58, 43-54. https://doi.org/10.1016/j.eap.2018.01.001

Ruxton, G. D. (2006). The unequal variance t-test is an underused alternative to Student's t-test and the Mann-Whitney U test. Behavioral Ecology, 17(4), 688-690. https://doi.org/10.1093/ beheco/ark016

Ugwu, C. C., Aikpitanyi, L. N., \& Idemudia, S. (2020). The Effect of Audit Quality on Financial Performance of Deposit Money Banks (Evidence from Nigeria). Journal of Economics and Business, 3(1). https://doi.org/10.31014/aior.1992.03.01.196

Ujunwa, A., Nwakoby, I., \& Ugbam, C. O. (2012). Corporate board diversity and firm performance: Evidence from Nigeria. Corporate Ownership and Control, 9(2 Continued 1), 216-223. https://doi.org/10.22495/cocv9i2c1art6 